\title{
CHANGES IN THE ECONOMY AS A SYSTEM: ENTREPRENEURSHIP UNDER THE INFLUENCE OF COVID-19
}

\author{
*Tatjana Lejava, Baiba Rivza, Maiga Kruzmetra \\ Latvia University of Life Sciences and Technologies, Latvia \\ *Corresponding author's email: tatjana.lejava@1lu.lv
}

\begin{abstract}
This research paper summarises the results of the rapid changes in the structure of the economic system as a result of the impact of the Covid-19 pandemic in 2020.

The following tasks were set for the research: to describe the national economic system before COVID-19 pandemic in Latvia, to identify and assess the main features of changes in the national economic system during 2020 and to identify and assess the geographical location of structural changes in the country.

The obtained results indicate three main tendencies in the structure of the economic system. Some economic segments indicate that the number of employees has increased in the time of the pandemic influence, some almost remained unchanged or experienced a decrease. As the linear changes in the volume of employees in the elements of the main structure of the economy take place to a different extent, then there is also an increase or decrease in the share of certain main segments in the regions of Latvia.
\end{abstract}

Key words: COVID-19, economic system, employment rate, regional economics, structural changes.

JEL code/ classification: P27; R12

\section{Introduction}

Any development identifies itself as a process of growth and change, characterised by a number of important differences. One of the most important differences is that if all components of the system develop evenly, the linear growth of the entire system is also pronounced. On the other hand, if the components of the system have different growth rates, structural changes develop. This fully applies to the economy of any country as an economic system. It is important that the increase in the share of one of the components of this economic system - the national economy- is related to the content and organisational development of innovative activities (Ogoko, 2016; OECD, 2015; European Commission, 2021).

The economy as a system of understanding and the process of changing this system has become an essential problem for scientific and political analysis. The combination of different elements is not a system. It becomes a system only when the elements that make up this system interact and changes in each individual element have a greater or lesser effect on other elements of the system and thus bring changes in the structure of the economic system by changing the positions of individual elements (Askoff, 2018; Tulonen, 2018). Influenced by this aspect, the Fourth Industrial Revolution is widely discussed at the beginning of the $21^{\text {st }}$ century as an important component of the changes ranking place in humanity as a whole (Schwab, 2016; Bachtler et al., 2019).

Over time, the study of the economy as a system has become the object of research in several regions of the world, such as the European Union (EU), Latin America and the Caribbean, as well as in individual counties such as Japan, Russia and, obviously, also Latvia research object (OECD, 2015; Nishi,
2015; Mironov \& Konovalova, 2019; Mihnenoka \& Šenfelde, 2017; Rivza, Kruzmetra, \& Jeroscenkova, 2019; Rivza, Kruzmetra, \& Rivza, 2020).

If authors' previous studies covered the processes of change over a longer period of time, this paper summarises the results of the rapid changes in these processes as a result of the impact of the COVID-19 pandemic in 2020, which can be formulated as the object of the current study.

The following research tasks were set in the research process: 1) to characterise the national economic system development tendencies before COVID-19 pandemic in Latvia, 2) to identify and assess the main features of changes in the national economic system during 2020,3 ) to identify and assess the geographical location of structural changes in the country.

\section{Materials and Methods}

For theoretical framework of the research, relevant scientific research papers, using monographic synthesis and analysis methods have been used. For the analysis, the statistical data and information sources from the European Innovation Scoreboard (European Commission, 2020), Eurostat classification of industries (European Commission, 2008), and Central Statistical Bureau of Latvia (CBS) including data on changes in the national economy in the period 2010 - 2018 and in-depth on changes during 2020 were taken.

Obtained data were processed by descriptive statistical analysis methods, as well as the grouping method, based on important indicators as to the number of employees in the respective economic segment. The information obtained during the grouping also opens the possibility to identify linear and structural changes 
in the economic situation in the country as a whole and in the planning regions of the country.

\section{Results and Discussions}

As noted in European Innovation Scoreboard, Latvia is included in the group of EU countries as a moderate innovator that is characterised by rapid growth and, consequently, in terms of economic indicators, is approaching the average level of development of the EU countries. If the average performance change EU between 2012 and 2019 improved by 8.9 percentage points, then for five Member States the performance improved by 20 percentage points or more. Latvia is included in 20 percentage points (\%-points), showing the most pronounced growth increase with an indicator 23.3\%-points. This positive result is provided 'Total Entrepreneurial Activity... and Enterprise births' (European Commission, 2020).

National economic system before the COVID-19 pandemic

According to the latest data, which characterise the structure of the economic system in a year, such a view is formed regarding main trends of changes in the period from 2010 until and including 2018 (Figure 1).

During the calculations, the obtained data confirm both the increase in the number of employees and the increase of net turnover of the companies as a result of economic activity. More important results are that show the predominance of net turnover growth over employment growth. Exactly these results most clearly present the changes taking place in the economic system. Growth of occupied jobs and net turnover of enterprises in comparison to the analysed period leads to conclusions that three options for change are possible. First - as the number of employees increases, the net turnover of the respective economic segment also increases. Second - as the number of employees decreases, the net turnover of the respective economic segment can also decrease. The third option is when the number of employees decreases, but at the same time the significant increase in net turnover of the national economic activities is observed. An example is the Financial and Insurance activities segment $(\mathrm{K})$, wherein in the period covered by the study, i.e., 2018 compared to 2010, the number of employees decreases to $87.4 \%$, but the net turnover of the national economic activities has a significant increase $242.0 \%$. Lest to analyse the structural changes in the economic system, it is necessary to pay attention to the fact that structural changes are taken not only in the economy as a whole system, but also within its segments (Rivza, Kruzmetra, \& Jeroscenkova, 2019). A considered example is the changes in the internal structure of the Information and Communication

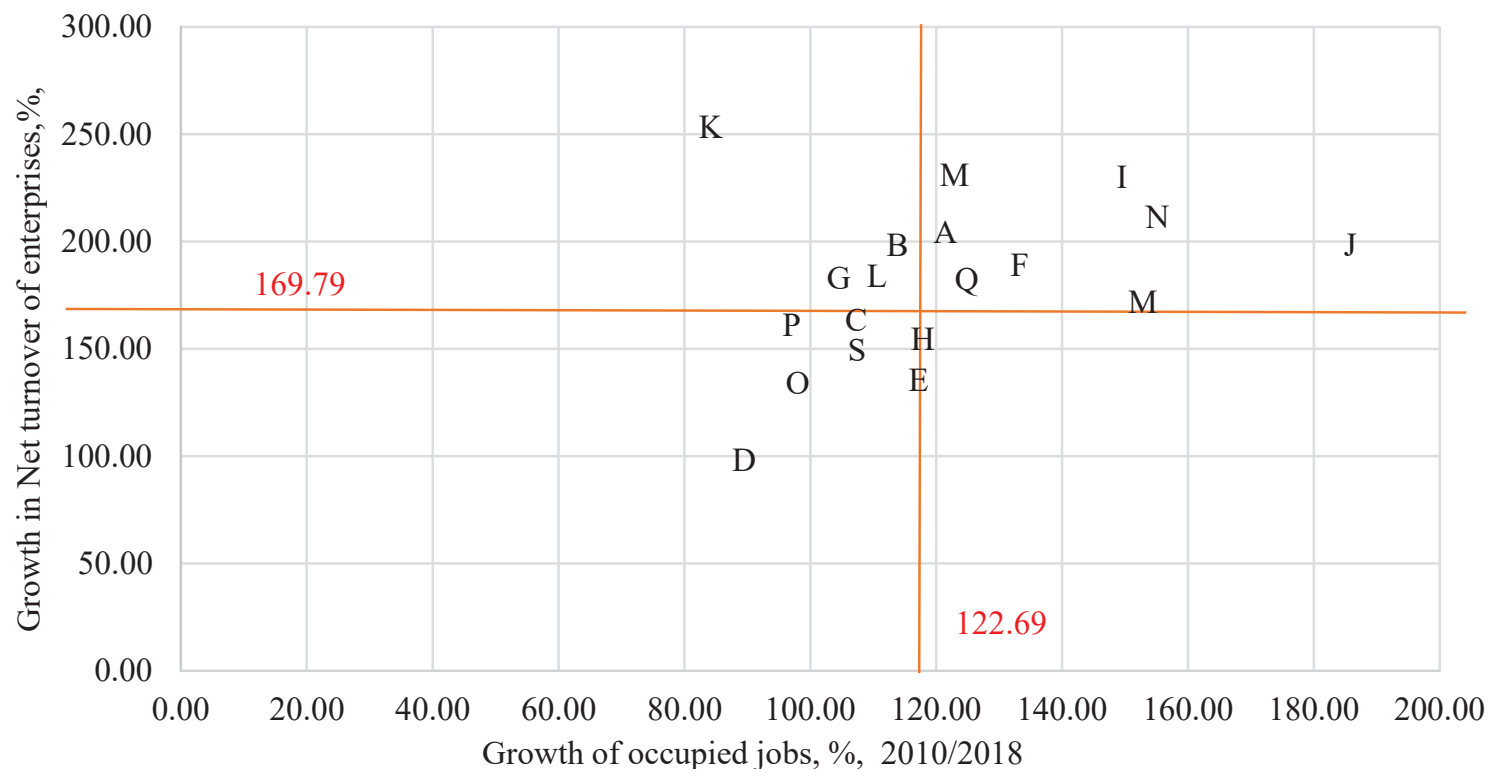

Figure 1. Changes in the Latvian economic system during 2010-2018.

A - Agriculture, forestry and fishing; B - Mining and quarrying; C - Manufacturing; D - Electricity, gas, steam and air conditioning supply; E - Water supply, sewerage, waste management and remediation activities; F - Construction; $\mathrm{G}$ - Wholesale and retail trade; repair of motor vehicles and motorcycles; $\mathrm{H}$ - Transportation and storage; I-Accommodation and food service activities; J - Information and communication; K - Financial and insurance activities; L - Real estate activities; M - Professional, scientific and technical activities; N - Administrative and support service activities; $\mathrm{O}$ - Public administration and defence; compulsory social security; P - Education; Q - Human health and social work activities; $\mathrm{R}$ - Arts, entertainment and recreation; $\mathrm{S}$ - Other service activities (European Commission, 2008).

Source: Authors' compiled based on Central Statistical Bureau of Latvia 2020 data. 
Changes in the structure of Latvia's economic segments in 2020 until the end of the $3^{\text {rd }}$ quarter

\begin{tabular}{|c|c|c|}
\hline \multicolumn{3}{|c|}{$\begin{array}{c}\text { Calculation of changes in the number of employees: } 100.0 \% \text { in the } 4^{\text {th }} \text { quarter of 2019, } \\
\text { but } \begin{array}{c}9.6 \% \text { in the } 3^{\text {rd }} \text { quarter of } 2020\end{array}\end{array}$} \\
\hline Groups & $\begin{array}{c}\text { Number of } \\
\text { segments }\end{array}$ & $\begin{array}{c}\text { Economic activities segments included in a group indi- } \\
\text { cated in \% }\end{array}$ \\
\hline $\begin{array}{c}\text { Group 1 - Increase in the number of em- } \\
\text { ployees - over 100.0\% }\end{array}$ & 7 & $\begin{array}{c}\text { A-107.2, B-135.0, F-100.8, J-100.3, } \\
\text { O-101.2, P-100.7, Q-102.8 }\end{array}$ \\
\hline $\begin{array}{c}\text { Group 2 - Insignificant reduction - less } \\
\text { than average }\end{array}$ & 1 & C-99.2 \\
\hline $\begin{array}{c}\text { Group 3 - The reduction is higher than } \\
\text { average }\end{array}$ & 11 & $\begin{array}{c}\text { D-94.9, E-97.3, G-98.0, H-93.0, I-86.6, K-96.5, L-97.9, } \\
\text { M-94.9, N-96.5, R-93.0, S-94.6 }\end{array}$ \\
\hline
\end{tabular}

A - Agriculture, forestry and fishing; B - Mining and quarrying; C - Manufacturing; D - Electricity, gas, steam and air conditioning supply; E - Water supply, sewerage, waste management and remediation activities; F - Construction; G Wholesale and retail trade; repair of motor vehicles and motorcycles; $\mathrm{H}$ - Transportation and storage; I - Accommodation and food service activities; J - Information and communication; K - Financial and insurance activities; L - Real estate activities; $\mathrm{M}$ - Professional, scientific and technical activities; $\mathrm{N}$ - Administrative and support service activities; $\mathrm{O}$ - Public administration and defence; compulsory social security; P - Education; Q - Human health and social work activities; R Arts, entertainment and recreation; $\mathrm{S}$ - Other service activities.

Source: Authors' calculations based on Central Statistical Bureau of Latvia.

services group $(\mathrm{J})$ segment based on the results of calculations.

Within a segment of economic structure, differences may arise between the components with segment. In general, if the growth of the segment's net turnover lags behind the growth of the number of employees, then certain components or subsegments of this segment show a significant increase in productivity and innovative productivity of employees in this segment - Computer programming, consultancy and related activities (J62) net turnover growth $-359.6 \%$ and Information service activities (J63) net turnover increase up to $413.8 \%$.

The main features of the changes that occurred in 2020 in the national economic system

In 2020, the Covid-19 pandemic has undoubtedly had an impact not only public health but also on the economy as an important area of public welfare. One of the most important indicators of change is the change in the number of employees. It is also extensively used in European Innovation scoreboard calculations (European Commission, 2020). Using the calculated data on employment in the segments of the economic system at the end of the $3^{\text {rd }}$ Quarter of 2020, the following view has been formed on the changes that have taken place as a result of the impact of the Covid-19 pandemic. There are segments in which, despite the difficult pandemic situation, an increase in the number of employees can be observed, reaching its maximum in Mining and quarrying segment (B $135.0 \%)$. At the same time, economic segments with the maximum decrease in the number of employees also stand out, where the Arts, entertainment, and recreation segment $(\mathrm{R}-93.0 \%)$ suffers the greatest losses, and even more so the Accommodation and food service activities segment (I - 86.6\%), which are closely related to the restrictions introduced in Latvia in order to reduce the spread of Covid-19. If the reduction of the number of employees in each segment of the economic system in comparison with the average indicator for the analysis is selected as a criterion for data analysis, three variations of changes are formed, where economic activities segments were compiled in groups. Group 1 - the number of employees at the end of the $3^{\text {rd }}$ quarter of 2020 exceeds the number of employees at the end of the $4^{\text {th }}$ quarter of 2019 , which is assumed by $100.0 \%$ in this segment. Group 2 - the reduction in the number of employees is minimal, i.e., less than the average reduction. Group 3 - the reduction in the number of employees is higher than average and reveals the economic system is most affected by the pandemic (Table 1).

The impact of the Covid-19 pandemic is manifested not only in the economic system as a whole, slowing down the activity of one or the other segment, but in a differentiated way affecting the internal structure of the segment, i.e. subsegments. If the number of employees in Manufacturing as a whole has decreased by $1.8 \%$-points compared to the situation at the end of the $4^{\text {th }}$ quarter of 2019 , then in some sectors of this segment this change is different: if the number of employees in Manufacture of basic metals (C24) has increased to $108.4 \%$ in the three quarters of 2020 , then in Manufacture of coke and refined petroleum products (C19) it has decreased to $36.5 \%$. This fact once again confirms that the economic system must be analysed 


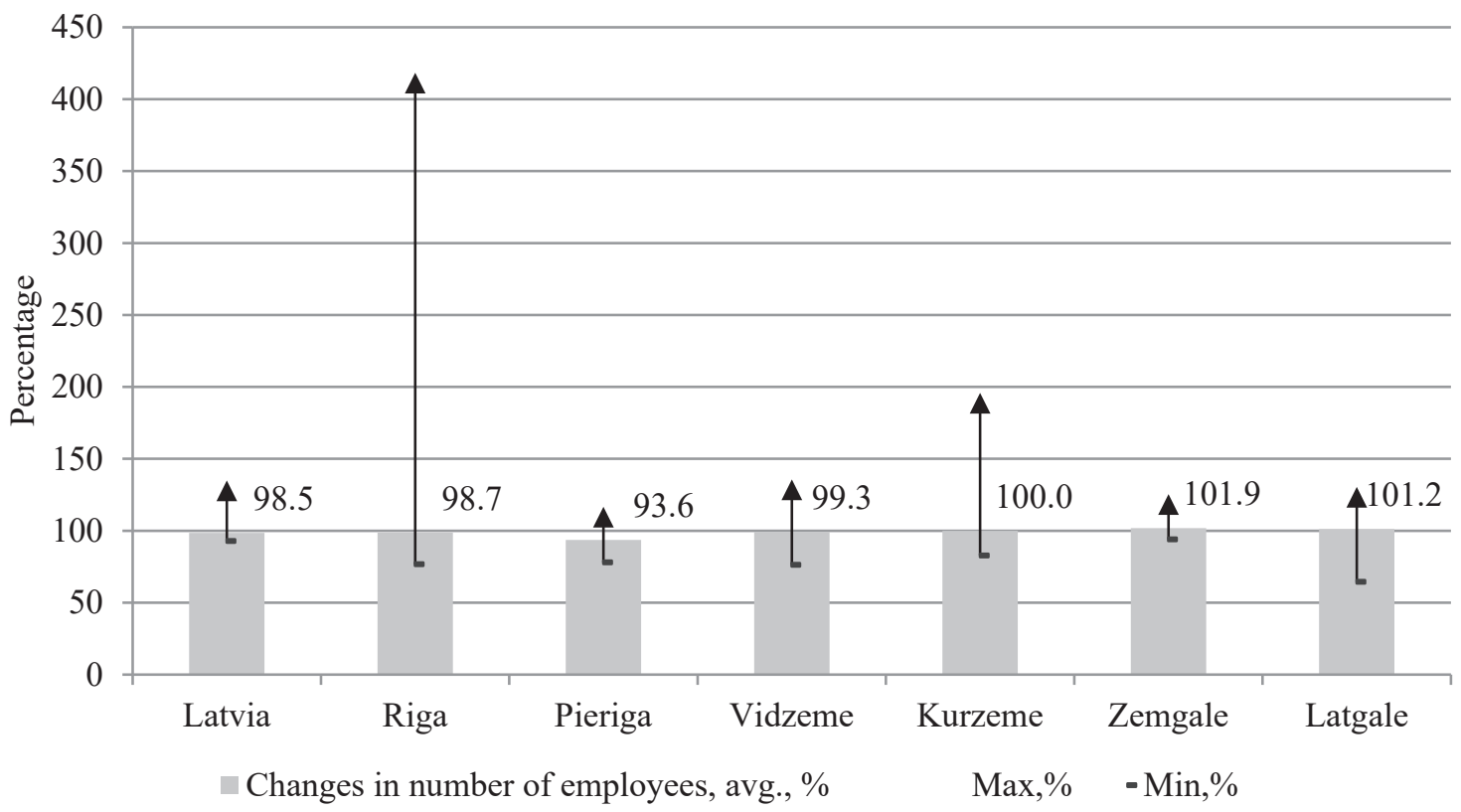

Figure 2. Changes in the structure of economic segments in regions of Latvia in 2020 until the end of the $3^{\text {rd }}$ quarter.

Source: Authors' compiled based on Central Statistical Bureau of Latvia data.

not only from the point of view of the main economic segments, but also analyse the internal structural changes of the most important segments, such as Agriculture, forestry and fishing (A), Manufacturing (C), Information and communication (J), and Financial and insurance activities $(\mathrm{K})$. The results obtained during the analysis logically raise the question - are the variations of these employment changes determined only by the Covid-19 pandemic and the restrictions on the movement and concentrations of people introduced during it? Or, no less, but even more, the shortcomings of the system of support of economic activity developed by governments? The analyses of the economic activity support system implemented by governments is a topical scientific research task. And the activity can begin to develop, obtaining a sufficient amount of content of information on all developments in the economic system and its structural changes.

Geographical location of structural changes in the economy as a system in Latvia

The Aggregate performance indicators (API) of any country provide an opportunity to assess the positions of a represented country outside the borders, for example, Latvia in the EU or in the group of Baltic States. Changes in the economic system as a whole and the structures included in it, can be viewed not only by sectors or segments, but also in a spatial or geographical breakdown. These are economic activity planning regions and Latvia is statistically indicated into the following six regions: Riga, Pieriga, Vidzeme, Kurzeme, Zemgale and Latgale regions. As the Covid-19 pandemic covers the entire territory of the Latvia, it was decided to analyse not only structural changes in the economic system but also geographical breakdown - each statistical region separately, preforming the framework of research work. Consequently, the research aim expanded, not only to identify changes in the structure of the economic system by planning regions but to compare the course of these processes within the state and to determine whether common and different features are observed (Figure 2).

The calculated percentage changes show that the economic system of each planning region of Latvia has undergone linear changes in separate segments results in segments are different, each showing different tendencies - some segments indicate that the number of employees had increased, some almost remained unchanged or experienced a smaller or larger decrease. As the linear changes in the volume of employees in the elements of the main structure of the economy take place to a different extent, then, of course, there is also an increase or decrease in the share or certain main segments in the region. Finding such changes, the question arises - in which basic segments of the economy by regional breakdown, there is an increase in employment and where the indicators indicate a decrease. Analysing the economic segments by groups, according to changes in the number of employees (Table 1), quite different tendencies emerge in the economic systems by the planning regions of Latvia (Figure 3). 


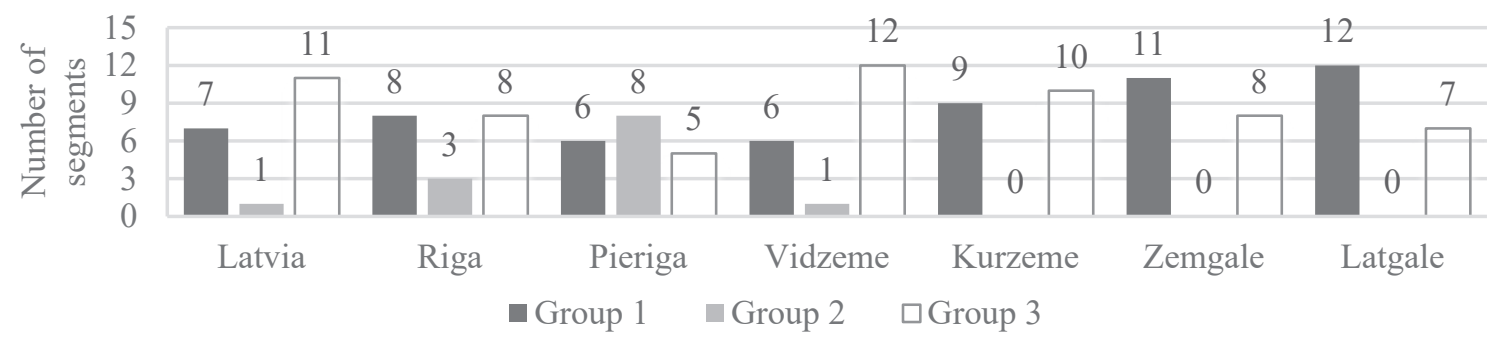

Figure 3. Changes in the number of employees in the planning regions of Latvia in the main segments of economy

Group 1 - Increase in the number of employees - over 100.0\%; Group 2 - Insignificant reduction - less than average; Group 3 - The reduction is higher than average.

Source: Authors' calculations based on Central Statistical Bureau of Latvia data and according to the grouping obtained in Table 1.

The number of economic segments by groups is different when compared between all planning regions of Latvia. In Latgale and Zemgale regions, the number of basic segments in economy, in which the number of employees increased dominates, while Vidzeme and Kurzeme regions indicated the decrease of number of employees. In Riga region, there are equivalent changes in the groups, which indicate an increase and decrease of the number of employees in basic segments of economy. Optimal indicators have been determined in the Pieriga region, as showing a smaller number of basic segments, where the number of employees is significantly decreasing. In the Pieriga planning region, the basic segments

\section{Comparison of structural changes of Zemgale and Vidzeme regions economic system}

\begin{tabular}{|c|c|c|c|c|}
\hline \multicolumn{5}{|c|}{$\begin{array}{l}\text { Calculation of changes in the number of employees: in the } 4^{\text {th }} \text { quarter of } 2019 \text { is } 100.0 \% \text {, } \\
\text { but in the } 3^{\text {rd }} \text { quarter of } 2020 \text { is } 98.6 \%\end{array}$} \\
\hline \multirow[t]{2}{*}{ Groups } & $\begin{array}{l}\text { Number of } \\
\text { segments }\end{array}$ & $\begin{array}{l}\text { Economic activities seg- } \\
\text { ments included in group } \\
\text { indicated in } \%\end{array}$ & $\begin{array}{l}\text { Number of } \\
\text { segments }\end{array}$ & $\begin{array}{c}\text { Economic activities segments } \\
\text { included in group indicated } \\
\text { in } \%\end{array}$ \\
\hline & \multicolumn{2}{|c|}{ Zemgale region } & \multicolumn{2}{|r|}{ Vidzeme region } \\
\hline $\begin{array}{l}\text { Group } 1 \text { - Increase in the } \\
\text { number of employees - over } \\
100.0 \%\end{array}$ & 11 & $\begin{array}{c}\text { A-117.4, B-114.1, } \\
\text { C-102.4, D-101.0, } \\
\text { F-103.5, I-125.5, } \\
\text { J-101.3, L-102.9, } \\
\text { M-105.7, O-101.7, } \\
\text { S-104.5 }\end{array}$ & 6 & $\begin{array}{l}\text { A-112.2, } \\
\text { B-135.7, } \\
\text { E-125.7, } \\
\text { I-113.0, } \\
\text { M-133.7, } \\
\text { Q-101.4 }\end{array}$ \\
\hline $\begin{array}{l}\text { Group } 2 \text { - Insignificant reduc- } \\
\text { tion - less than average }\end{array}$ & $\mathbf{0}$ & - & 1 & O-99.9 \\
\hline $\begin{array}{l}\text { Group } 3 \text { - The reduction is } \\
\text { higher than average }\end{array}$ & 8 & $\begin{array}{l}\text { E-94.0, G-99.5, } \\
\text { H-98.4, K-94.8, } \\
\text { N-95.2, P-97.8, } \\
\text { Q-97.8, R-97.6 }\end{array}$ & 12 & $\begin{array}{l}\text { C-97.0, D-79.6, } \\
\text { F-94.2, G-99.0, } \\
\text { H-97.2, J-93.4, } \\
\text { K-76.3, L-97.2, } \\
\text { N-80.4, P-96.4, } \\
\text { R-95.8, S-78.1 }\end{array}$ \\
\hline
\end{tabular}

A - Agriculture, forestry and fishing; B - Mining and quarrying; C - Manufacturing; D - Electricity, gas, steam and air conditioning supply; E - Water supply, sewerage, waste management and remediation activities; F - Construction; $\mathrm{G}$ - Wholesale and retail trade; repair of motor vehicles and motorcycles; $\mathrm{H}$ - Transportation and storage; I-Accommodation and food service activities; J - Information and communication; K - Financial and insurance activities; L - Real estate activities; $\mathrm{M}$ - Professional, scientific and technical activities; $\mathrm{N}$ - Administrative and support service activities; $\mathrm{O}$ - Public administration and defence; compulsory social security; P - Education; Q - Human health and social work activities; $\mathrm{R}$ - Arts, entertainment and recreation; $\mathrm{S}$ - Other service activities.

Source: Authors' calculations based on Central Statistical Bureau of Latvia data. 
have a marked minimum reduction in the number of employees.

For a further analysis, Latgale and Zemgale regions data to analyse the changes in economic system in conditions of Covid-19 pandemic have been selected. Thus, a broader explanation of changes taking place in the regional economic system is obtained (Table 2).

A comparison of the processes shows that:

- In four segments (A, B, I and M) there is an increase in the number of employees in both regions;

- In six segments ( $\mathrm{G}, \mathrm{H}, \mathrm{K}, \mathrm{N}, \mathrm{P}$ and $\mathrm{R})$ there is a reduction in the number of employees in both regions;

- In nine segments $(\mathrm{C}, \mathrm{D}, \mathrm{E}, \mathrm{F}, \mathrm{J}, \mathrm{L}, \mathrm{O}, \mathrm{Q}$ and $\mathrm{S})$ comparing the regions are opposite changes, i.e., in Vidzeme region the number of employees in 2 segments ( $\mathrm{E}$ and $\mathrm{Q}$ ) is increasing, but in Zemgale region it is decreasing, while in Zemgale region, the number of employees in 7 segments $(\mathrm{C}, \mathrm{D}, \mathrm{F}, \mathrm{J}, \mathrm{L}, \mathrm{O}$ and $\mathrm{S})$ is increasing, but in Vidzeme region is decreasing.

The national framework regulations to mitigate the effects of the Covid-19 pandemic apply to all the national economy including all parts of it. Therefore, it is not clear what affects the differences within the same economic segment in each of the country's region. It is unclear if subjective circumstances, such as people's readiness to adapt to ongoing changes in economy and the competence of governance structures in the regions play a leading role. However, it is clear that solutions to existing issues can be found in further research.

If the results of the research process are accepted as sufficiently significant, it is possible that the national business support system for the maintenance and successful promotion of economic activities should also include a specific aid regulation from a regional perspective.

\section{Conclusions}

In accordance with the set tasks, the data analysis leads to the following conclusions:

1) The national economic system development tendencies before COVID-19 pandemic in Latvia have shown quite a significant growth. Digitizationrelated industries are particularly prominent. The highest growth rates in terms of employment are shown by economic segments such as Information and communication $(\mathrm{J})-189.0 \%$; Administrative and support service activities (N) - 156.3\%; Professional, scientific and technical activities (M) - 156.1\%; Accommodation and food service activities (I) $151.9 \%$. But if we compare the increase in net turnover of the companies, the highest growth rates are in economic segments such as Financial and insurance activities (K) - 242.0\%; Arts, entertainment and recreation $(\mathrm{R})-218.5 \%$; Accommodation and food service activities (I) $-218.1 \%$; Administrative and support service activities $(\mathrm{N})-196.7 \%$. Although the growth rate between indicators is different, it should be emphasised that more important results are those that show the predominance of net turnover growth over employment growth.

2) The COVID-19 pandemic has affected each state's economy, including Latvia, bringing changes to the economy the main features of changes in the national economic system during 2020. The case of Latvia shows that during the last year several restrictions were implemented, with the aim to reduce the rapid spread of infection, but as a result of these restrictions, in several sectors economically active companies were led to the suspension. One of the main consequences of economic activity suspension is a reduction of the number of employees in specific sectors. According to the results of the study, changes in the number of employees, comparing the results of the $4^{\text {th }}$ quarter of 2019 (assuming by $100.0 \%$ ) to the $3^{\text {rd }}$ quarter of 2020 were analysed, and it can be concluded that the most affected sectors are related to the provision of services, such as Accommodation and food service activities segment (I) $-86.6 \%$, which is directly related to the restrictions affecting the tourism sector, as well as Transportation and storage segment (H) $-93.0 \%$ and Arts, entertainment and recreation (R) $-93.0 \%$. In total, 11 of 19 economic segments showed a decrease in the number of employees, indicating that solutions and support mechanisms need to be found to improve results of employment. To get a clearer understanding of the whole economic system, it must be analysed not only from the point of view of the main economic segments but also to analyse the internal structural changes of the most meaningful segments of the country.

In order to maintain the possibility to hold an economic activity in existing conditions, it is necessary to reorient economic activity, seeking solutions for successful further development. Although various financial support mechanisms are being developed and offered to Latvian suffered entrepreneurs from the COVID-19 pandemic influence, a more important role should be given to support that would encourage entrepreneurs to look more broadly and try to adapt their economic activities to the current situation. As one of the tools would be to promote good practice, through the media or other public information tools, showing suffered entrepreneurs the possible solutions that could be implemented to sustain economic activity. The innovative approach and adaptability in some cases can be the key to problem-solving.

3) Data analysis makes it possible to identify the geographical location of structural changes in the 
country, which shows that the processes of change caused by the pandemic are not the same in the regions of the country. Results indicate that the economic system of each region of Latvia has undergone linear changes in separate segments and results in segments showing different tendencies. In Latgale and Zemgale regions more basic segments indicate an increase in the number of employees, while Vidzeme and Kurzeme regions number of employees is decreasing. Comparing data of Latgale and Zemgale regions, it was more important to discover those nine segments that show opposite changes. In the Vidzeme region, an increase in the number of employees is identified at segments Water supply, sewerage, waste management and remediation activities (E) - 125.7\% and Human health and social work activities (Q) $-101.4 \%$, while in the Zemgale region, the decrease E-94.0\% and Q $97.8 \%$ is observed.

In order to better assess the changes brought about by the pandemic, a longer period of time is needed, which will provide more and detailed information on the changes caused. Particular attention should be paid to the growth of exports and sale markets in the country in order to be able to make proposals for the development of the strategy for the further development of the country's economic system. Policy-makers need to base their decisions on the research of structural changes in the national economy, targeting the support mechanisms in future for those, who can try to adapt to existing constraints. The authors consider that research on structural change in the economic system needs to be done more precisely, analysing the structural changes at the subsegments level.

\section{Acknowledgements}

The paper was supported by National Research Program project 'Towards the Post-pandemic Recovery: Economic, Political and Legal Framework for Preservation of Latvia's Growth Potential and Increasing Competitiveness (recovery-LV)'.

\section{References}

Ackoff, R. (2018). A Lifetime of Systems Thinking. Retrieved February 5, 2021, from https://thesystemsthinker. com/a-lifetime-of-systems-thinking/.

Bachtler, J., Martins, J.O., Wostner, P., \& Zuber, P. (2019). Towards Cohesion Policy 4.0: Structural Transformation and Inclusive Growth. New York, USA: Taylor and Francis Group.

Central Statistical Bureau. (2020, a). Komersantu neto apgrozijums par darbïbas veidiem (NACE 2.red.) (milj. euro) (Net turnover of enterprises by type of activity (NACE Rev.2) (million euro)). Retrieved February 5, 2021, from https://www.csb.gov.lv/lv/statistika/statistikas-temas/uznemumi/uznemejdarbibas-finanses/ tabulas/ufg030/komersantu-neto-apgrozijums-pa-darbibas. (in Latvian).

Central Statistical Bureau. (2020, b). Aizņemtās darbvietas pa darbības veidiem vidēji gadā (Occupied jobs by type of activity on average per year). Retrieved February 5, 2021, from https://www.csb.gov.lv/lv/ statistika/statistikas-temas/socialie-procesi/darbvietas/tabulas/jvsg010/aiznemtas-darbvietas-pa-darbibasveidiem. (in Latvian).

Central Statistical Bureau. (2020, c). Aizṇemtās darbvietas reǵionos pa darbības veidien ceturkšṇa beigās (Occupied jobs in regions by type of activity at the end of the quarter). Retrieved February 5, 2021, from https://www.csb.gov.lv/lv/statistika/statistikas-temas/socialie-procesi/darbvietas/tabulas/jvs014c/ aiznemtas-darbvietas-regionos-pa-darbibas. (in Latvian).

European Commission. (2008). NACE Rev.2 Statistical classification of economic activities in the European Community. Luxembourg: Office for Official Publications of the European Communities.

Economic Commission for Latin America and the Caribbean. (2008). Structural Change and productivity Growth. 20 Years Later. Old problems, new opportunities. Santiago, Chile: United Nations.

European Commission. (2021, February). Structural reforms for economic growth. Retrieved February 5, 2021, from https:/ec.europa.eu/info/business-economy-euro/growth-and-investment/structural-reforms/ structural-reforms-economic-growth_en.

European Commission. (2020, June). European innovation scoreboard 2020. Retrieved February 5, 2021, from https://ec.europa.eu/docsroom/documents/42981.

Mihņenoka, A., \& Šenfelde, M. (2017). The Impact of National Economy Structural Transformation on Regional Employment and Income: The Case of Latvia. South East European Journal of Economics and Business. 12(2): 47.-60.lpp. DOI: 10.1515/jel-2017-0015.

Mironov, V.V., \& Konovalova, L.D. (2019). Structural changes and economic growth in the world economy and Russia. Russian Journal of Economics. 5 (2019), 1-26. DOI: 10.32609/j.ruje.5.35233.

Nishi, H. (2016). Structural Change and Transformation of Growth Regime in the Japanese Economy. Evolut Inst Econ Rev. 13, 183-215. DOI: 10/1007/s40844-016-0034-5.

OECD. (2015). Structural reforms in Europe. Achievements and Homework. Retrieved February 5, 2021, from https://www.oecd.org/eu/structural-reforms-in-europe-achievements-and-homework.pdf. 
Ogoko, G. (2016). Analysis of the structural change \& linear growth models of development. Retrieved February 5, 2021, from https:/www.linkedin.com/pulse/analysis-structural-change-linear-growth-models-geraldogoko.

Rivza, B., Kruzmetra, M., \& Jeroscenkova, L. (2019). Structural Redeployment of the Economy as an Important Step Towards Smart Growth. In $19^{\text {th }}$ International multidisciplinary scientific GeoConference SGEM 2019, 30 June - 6 July 2019 (pp. 713-720). Albena, Bulgaria: Bulgarian Academy of Sciences. DOI: 10.5593/ sgem2019/5.3/S21.089.

Rivza, B., Kruzmetra, M., \& Rivza, P. (2020). Linear and structural changes in rural space - the positive and problematic aspects (case of Latvia). Open Agriculture. 5 (1), 669-676. DOI: 10.1515/opag-2020-0068.

Schwab, K. (2016). The Fourth Industrial Revolution. London: Penguin Books.

Tulonen, A. (2018, October). Ackoff and Systemic Thinking. Retrieved February 5, 2021, from https://www. aleksistulonen.com/2018/10/28/ackoff-and-systemic-thinking/. 